\title{
Pemberdayaan Masyarakat Pantai melalui Pelatihan Pengemasan Produk Destinasi Wisata dalam Perspektif Komunikasi Visual di Desa Kertayasa Kecamatan Cijulang Kabupaten Pangandaran
}

\author{
Yanti Setianti, Hanny Hafiar, Priyo Subekti \\ Program Studi Hubungan Masyarakat Fakultas Ilmu Komunikasi UNPAD \\ yantisetianti@gmail.com
}

\begin{abstract}
Community empowerment is a government program that is currently being promoted to create a creative society by recognizing the potential and existing problems surrounding the environment by exploiting local potential. One of the community empowerment efforts that is conducted by the PKM team of Public Relations Program of Fikom Unpad is through the training for community empowerment through the introduction of visual communication to design products to be more inviting and attract attention. The participants in this training consisted of youth leaders, community leaders, and village officials in terms of understanding about community empowerment through creative potential based on local creative training. Objects of activities of these institutions and figures were chosen because they are an important part of formal human resource management that exists in every village government as an element of supporting development activities in the real sector. The implementation method starts from the Preparation, Implementation and Evaluation Stage. Implementation using lecture method discussion.
\end{abstract}

Keywords: PKM, Community, Empowerment, Local Potency.

\section{Pendahuluan}

Kabupaten Pangandaran merupakan pemekaran dari Kabupaten Ciamis, yang resmi berdiri pada tanggal 25 Oktober 2012. Secara geografis kabupaten Pangandaran berbatasan dengan kabupaten Ciamis dan kota Banjar di utara, kabupaten Cilacap di timur, samudera Hindia di selatan, serta kabupaten Tasikmalaya di barat. Sedangkan secara administratif kabupaten Pangandaran terdiri atas 10 kecamatan yang terdiri atas sejumlah desa dan kelurahan dengan pusat pemerintahan kabupaten berada di kecamatan Parigi. Adapun 10 kecamatan tersebut adalah kecamatan Cigugur, kecamatan Cijulang, kecamatan Cimerak, kecamatan Kalipucang, kecamatan Langkaplancar, kecamatan Mangunjaya, kecamatan Padaherang, kecamatan Pangandaran, kecamatan Parigi, dan kecamatan Sidamulih.

Berdasarkan RTRWN (Rencana Tata Ruang Wilayah Negara) Kabupaten Pangandaran diklasifikasikan sebagai kawasan andalan dengan sektor unggulan pertanian tanaman pangan, industri, perkebunan dan kehutanan serta pariwisata. Kabupaten Pangandaran ditetapkan sebagai PKL (Pusat Kegiatan Lokal), yang meliputi pusat pengembangan dan pengelolaan yang mempunyai pelayanan satu kabupaten atau beberapa kecamatan, dengan kriteria penentuan pusat jasa keuangan/bank, pusat pengelolaan dan pengembangan kegiatan pertanian

Volume 2, Number 1, Mei 2018| 26

Pemberdayaan Masyarakat Pantai melalui Pelatihan Pengemasan Produk Destinasi Wisata dalam Perspektif Komunikasi Visual di Desa Kertayasa Kecamatan Cijulang Kabupaten Pangandaran Yanti Setianti, Hanny Hafiar, Priyo Subekti 
dan perkebunan, jasa pemerintahan yang mendorong pada sektor strategis.

Desa Kertayasa adalah salah satu desa di Kecamatan Cijulang, Kab.Pangandaran, Prov.Jawa Barat, yang mempunyai luas wilayah 1.355.610 Ha. Dilihat dari Topografi ketinggian wilayah Desa Kertayasa berada pada $+75 \mathrm{~m}$ ketinggian dari permukaan air laut dengan keadaan curah hujan rata-rata $20 \mathrm{~mm}$ /tahun, serta suhu rata-rata antara 27-30 C dengan kelembaban udara rata-rata $70 \%$ per tahun. Dan terbagi dalam beberapa peruntukkan lahan, seperti untuk Fasilitas Umum, Pemukiman, Pertanian, Kegiatan ekonomi dan lain-lain. Luas lahan yang diperuntukkan untuk perumahan kurang-lebih sekitar 18,60 Ha, untuk fasilitas jalandan dan fasilitas umum lainnya sekitar 56,80 Ha dan untuk pemakaman umum 6,83 Ha. Sedangkan lahan untuk aktifitas pertanian sekitar 871,195Ha : terdiri dari lahan sawah sekitar 257,77 Ha dan lahan kebun sekitar 613,425 Ha, lahan sawah irigasi setengah teknis 21,52 Ha dan lahan irigasi tadah hujan 236,25 Ha.

Lembaga pendidikan yang ada di desa Kertayasa ini terdapat 8 (delapan) Unit Lembaga Pendidikan yaitu 2 (dua) unit Taman Kanak-Kanak, 3 (tiga) unit Pondok Pesantren dan 3 (tiga) unit Sekolah Dasar. Struktur mata pencaharian masyarakat desa Kertayasa yaitu dalam sektor pangan (tani) sebanyak 1630 orang, sektor perkebunan sebanyak 1518 orang, sektor peternakan sebanyak 1571 orang.

Di wilayah desa Kertayasa ini terdapat 36 RT dan 14 RW dengan jumlah penduduk sebanyak 4136 orang, Kepala Keluarga (KK) sebanyak 1562 orang, Penduduk Laki-Laki sebanyak 2016 orang, dan Penduduk Perempuan sebanyak 2120 orang. Hampir semuanya masyarakat desa Kertayasa merupakan Warga Negara Indonesia (WNI), mayoritas suku Sunda dan pemeluk agama Islam dengan nuansa religi sangat terasa dan menonjol dalam kehidupan sehari-harinya.

Salah satu potensi yang dimiliki oleh desa Kertayasa adalah bidang pariwisata. Desa Kertayasa memiliki banyak tempat yang cukup indah dan berpotensi mendatangkan turis dalam negeri dan turis mancanegara. Desa Kertayasa yang terletak di dataran tinggi ini memiliki relief sungai yang tidak ada ditempat lain di Indonesia. Beberapa di antaranya yaitu Green Canyon atau Cukang Taneuh dan Green Coral dan Curug Taringgul. Tempat wisata tersebut berada di bawah kepengurusan dari Pemda yang bertanggung jawab dalam perawatan dan pemasaran lokasi wisata tersebut. Pada sektor pariwisata ini, infrakstruktur menjadi masalah utama, sulitnya akses ke objekobjek wisata tersebut dapat menurunkan minat para turis untuk mengunjunginya. Namun dalam hal pemasaran pemerintah daerah sudah mempromosikan objek-objek wisata tersebut mengunakan media-media internet.

Salah satu permasalahan yaitu kurangnya promosi wisata yang dilakukan oleh desa dan

Volume 2, Number 1, Mei 2018| 27

Pemberdayaan Masyarakat Pantai melalui Pelatihan Pengemasan Produk Destinasi Wisata dalam Perspektif Komunikasi Visual di Desa Kertayasa Kecamatan Cijulang Kabupaten Pangandaran 
karang taruna yang mengelola tempat wisata tersebut. Promosi wisata sudah dilakukan melalui internet tetapi pengelolaannya masih belum maksimal dilihat dari segi komunikasi visual dan penataan desain websitenya masih sederhana.

Komunikasi visual adalah suatu proses penyampaian pesan dimana lambang-lambang yang dikirimkan komunikator hanya ditangkap oleh komunikan semata-mata hanya melalui indra penglihatan. Bentuk komunikasi seperti ini bisa bersifat langsung, namun sebagian besar menggunakan media perantara yang lazim disebut media komunikasi visual. Komunikasi melalui penglihatan adalah sebuah rangkaian proses penyampaian infromasi atau pesan kepada pihak lain dengan penggunaan media penggambaran yang hanya terbaca oleh indera penglihatan. Komunikasi visual mengkombinasikan seni, lambang, gambar, desain grafis, ilustrasi, dan warna dalam penyampaiannya. Komunikasi visual dapat dimanfaatkan sebagai sarana presentasi dan promosi untuk menyampaikan pesan, mendapatkan perhatian (atensi) dari mata (secara visual) dan membuat pesan tersebut dapat diingat; contohnya poster, tampilan website, dan foto. Berdasarkan hal tersebut maka kami merumuskan permasalahan yaitu dengan melakukan pemberdayaan masyarakat melalui pengemasan produk (dalam hal ini adalah destinasi wisata) dalam perspektif komunikasi visual di desa Kertayasa kecamatan Cijulang kabupaten pangandaran.

Lahirnya konsep pemberdayaan sebagai antitesa terhadap model pembangunan yang kurang memihak pada rakyat mayoritas. Konsep ini dibangun dari kerangka logik sebagai berikut : (1) bahwa proses pemusatan kekuasaan terbangun dari pemusatan kekuasaan faktor produksi; (2) pemusatan kekuasaan faktor produksi akan melahirkan masyarakat pekerja dan masyarakat pengusaha pinggiran; (3) kekuasaan akan membangun bangunan atas atau system pengetahuan, sistem politik, sistem hukum dan sistem ideologi yang manipulative untuk memperkuat legitimasi; dan (4) pelaksanaan sistem pengetahuan, system politik, sistem hukum dan ideologi secara sistematik akan menciptakan dua kelompok masyarakat, yaitu masyarakat berdaya dan masyarakat tunadaya ${ }^{1}$.

Dalam konsep pemberdayaan, menurut Prijono \& Pranarka, manusia adalah subyek dari dirinya sendiri. Proses pemberdayaan yang menekankan pada proses memberikan kemampuan kepada masyarakat agar menjadi berdaya, mendorong atau memotivasi individu agar mempunyai kemampuan atau keberdayaan untuk menentukan pilihan hidupnya ${ }^{2}$. Lebih lanjut dikatakan bahwa

\footnotetext{
${ }^{1}$ Prijono, \& Pranarka. "Pemberdayaan: Konsep, Kebijakan dan Implementasi” (Jakarta: Center for Strategic and International Studies. 1996)

2 Ibid
}

Volume 2, Number 1, Mei 2018| 28

Pemberdayaan Masyarakat Pantai melalui Pelatihan Pengemasan Produk Destinasi Wisata dalam Perspektif Komunikasi Visual di Desa Kertayasa Kecamatan Cijulang Kabupaten Pangandaran Yanti Setianti, Hanny Hafiar, Priyo Subekti 
pemberdayaan harus ditujukan pada kelompok atau lapisan masyarakat yang tertinggal.

Menurut Sumodiningrat, bahwa pemberdayaan masyarakat merupakan upaya untuk memandirikan masyarakat lewat perwujudan potensi kemampuan yang mereka miliki. Adapun pemberdayaan masyarakat senantiasa menyangkut dua kelompok yang saling terkait, yaitu masyarakat sebagai pihak yang diberdayakan dan pihak yang menaruh kepedulian sebagai pihak yang memberdayakan ${ }^{3}$.

Keberdayaan dalam konteks masyarakat adalah kemampuan individu yang bersenyawa dalam masyarakat dan membangun keberdayaan masyarakat yang bersangkutan. Suatu masyarakat yang sebagian besar anggotanya sehat fisik dan mental, terdidik dan kuat, tentunya memiliki keberdayaan yang tinggi. Keberdayaan masyarakat merupakan unsur dasar yang memungkinkan suatu masyarakat bertahan, dan dalam pengertian yang dinamis mengembangkan diri dan mencapai kemajuan. Keberdayaan masyarakat itu sendiri menjadi sumber dari apa yang di dalam wawasan politik disebut sebagai ketahanan nasional.

Tujuan dari kegiatan Pemberdayaan Masyarakat di Desa Kertayasa Kecamatan Cijulang Kabupaten Pangandaran ini diantaranya:

1. Untuk meningkatkan wawasan dan pengetahuan peserta dalam hal ini masyarakat mengenai pentingnya mengembangkan potensi ekonomi kreatif di wilayahnya.

2. Untuk meningkatkan pemahaman peserta dalam hal ini masyarakat mengenai pentingnya mengembangkan potensi ekonomi kreatif di wilayahnya

3. Untuk meningkatkan keterampilan praktis (industry kreatif) berbasis general life skills (personal skill, social skill, academic skill, vocasional skill, dan spiritual skill) dan memiliki kesadaran untuk meningkatkan kualitas diri untuk terus belajar sepanjang hayat (life long education).

Kegiatan pengabdian kepada masyarakat ini mempunyai manfaat bukan hanya untuk masyarakat sendiri melainkan juga bagi berbagai pihak yang terkait dengan masalah ini. Adapun target dan luaran pengabdian kepada masyarakat ini adalah:

1. Bagi masyarakat, pengabdian kepada masyarakat ini diharapkan dapat memberikan pengetahuan, pemahaman dan keterampilan yang berguna bagi peningkatan kesejahteraan melalui pengembangan ekonomi kreatif.

2. Bagi pihak Unpad, kegiatan ini merupakan wujud nyata adanya keterkaitan dan kepedulian Unpad terhadap upaya pemerintah dalam meningkatkan kesejahteraan masyarakat.

\footnotetext{
${ }^{3}$ Sumodiningrat, G. "Pemberdayaan Masyarakat dan Jaring Pengaman Sosial” (Jakarta: Gramedia.1999)
} 
3. Bagi pemerintah baik pusat maupun daerah, pengabdian kepada masyarakat ini dapat ikut berperan serta secara aktif dalam upaya pemerintah meningkatkan ekonomi masyarakat melalui program ekonomi kreatif.

4. Publikasi ilmiah berupa publikasi di Jurnal Nasional ber ISSN atau seminar nasional yang terkait dengan tema pengabdian kepada masyarakat

\section{Metode}

Kegiatan PKM ini merupakan salah satu program perguruan tinggi yang bekerjasama dengan pihak pemerintahan kabupaten/propinsi untuk dapat mengembangkan indeks pembangunan manusia (IPM) dengan melibatkan perguruan Tinggi. Kegiatan PKM ini diharapkan menjadi forum komunikasi, silahturahmi, advokasi, penerangan dan pendidikan sekaligus wadah kegiatan penguatan fungsi dan peran masyarakat dalam meningkatkan pembangunan desa secara immateri maupun materi yang selanjutnya bisa dikembangkan sebagai wadah pelayanan masyarakat di bidang pelayanan kesehatan, pendidikan, wirausaha, dan pengembangkan lingkungan yang memudahkan masyarakat berkembang secara mandiri.

Tabel 1. Indikator keberhasilan kegiatan (utama dan penunjang) seperti format berikut ini:

\begin{tabular}{clcl}
\hline No. & \multicolumn{1}{c}{ Indikator } & Sebelum Kegiatan & \multicolumn{1}{c}{ Setelah Kegiatan } \\
\hline 1 & Persiapan : Pemetaan & - Koordinasi dengan & - Koordinasi dengan para \\
& Kebutuhan Khalayak & pihak pemerintah & mahasiswa kelas Pangandaran \\
dan Koordinasi dengan & setempat. & sehingga memperoleh data \\
pihak terkait. & - Koordinasi dengan & khalayak sasaran. \\
& pihak sekolah. & - Terjalin koordinasi yang baik \\
& - Koordinasi dengan & dengan pihak pemerintah setempat \\
& mahasiswa kelas & dan pihak sekolah, termasuk \\
& Pangandaran & mendapatkan perijinan dan lokasi \\
& & pelaksanaan. \\
\hline 2 & Pelaksanaan : & - Mempersiapkan & - Sarana dan prasarana tersedia. \\
Mengadakan pelatihan & sarana prasarana. & - Peserta hadir dalam kegiatan. \\
pemberdayaan & - Mempersiapkan & - Peserta mengetahui manfaat \\
masyarakat melalui & bahan dan materi. & pelatihan. \\
pelatihan pengemasan & - Pemberian tugas & - Peserta Menguasai beberapa \\
produk destinasi wisata & & aplikasi dalam pelatihan \\
dalam perspektif & & \\
komunikasi visual & & \\
\hline
\end{tabular}

Volume 2, Number 1, Mei 2018|30

Pemberdayaan Masyarakat Pantai melalui Pelatihan Pengemasan Produk Destinasi Wisata dalam Perspektif Komunikasi Visual di Desa Kertayasa Kecamatan Cijulang Kabupaten Pangandaran Yanti Setianti, Hanny Hafiar, Priyo Subekti 
ENGAGEMENT

Jurnal Pengabdian Kepada Masyarakat

ISSN: 2579-8375 (Print)

ISSN: 2579-8391 (Online)
This work is licensed under a Creative Commons Attribution-ShareAlike 4.0 International License.

\section{BY SA}

\section{Hasil dan Diskusi}

\section{Kerangka Pikir Pelaksanaan PKM}

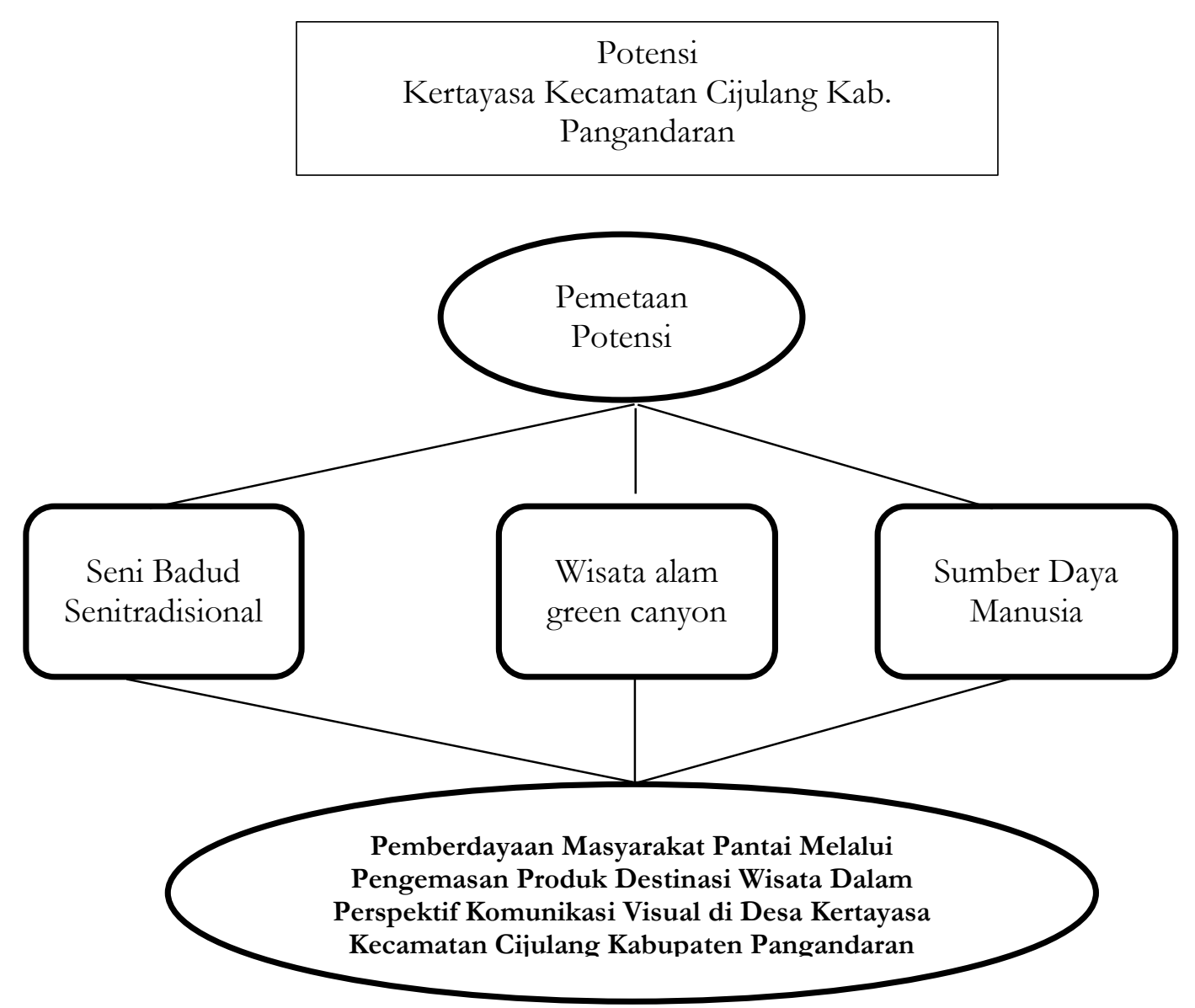

Tabel 2. Indikator Pelaksanaan PKM

\begin{tabular}{clcc}
\hline No. & \multicolumn{1}{c}{ Indikator } & Sebelum Kegiatan & \multicolumn{1}{c}{ Setelah Kegiatan } \\
\hline $\mathbf{1}$ & Persiapan : & - Koordinasi dengan & - Koordinasi dengan para mahasiswa kelas \\
& Pemetaan & pihak pemerintah & Pangandaran sehingga memperoleh data \\
& Kebutuhan & setempat. & khalayak sasaran. \\
Khalayak dan & - Koordinasi dengan & - Terjalin koordinasi yang baik dengan \\
& Koordinasi & pihak sekolah. & pihak pemerintah setempat dan pihak \\
dengan pihak & - Koordinasi dengan & sekolah, termasuk mendapatkan \\
& terkait. & mahasiswa kelas & perijinan dan lokasi pelaksanaan. \\
& & Pangandaran & \\
\hline
\end{tabular}

Volume 2, Number 1, Mei 2018|31

Pemberdayaan Masyarakat Pantai melalui Pelatihan Pengemasan Produk Destinasi Wisata dalam Perspektif Komunikasi Visual di Desa Kertayasa Kecamatan Cijulang Kabupaten Pangandaran 


$\begin{array}{lcl}\text { Pelaksanaan : } & \text { - Mempersiapkan } & \text { - Sarana dan prasarana tersedia. } \\ \text { Mengadakan } & \text { sarana prasarana. } & \text { - Peserta hadir dalam kegiatan. } \\ \text { pelatihan } & \text { - Mempersiapkan } & \text { - Peserta mengetahui manfaat } \\ \text { pengemasan } & \text { bahan dan materi. } & \text { pengemasan produk dalam perspektif } \\ \text { produk dalam } & & \text { komunikasi kreatif } \\ \text { perspektif } & & \text { - Peserta Menguasai beberapa aplikasi } \\ \text { komunikasi } & \text { pengemasan produk dalam perspektif } \\ \text { kreatif } & \text { komunikasi kreatif } \\ & \text { - Peserta mempraktekan pengemasan } \\ & \text { produk dalam perspektif komunikasi } \\ & \text { kreatif }\end{array}$

Kegiatan pengabdian masyarakat dilaksanakan pada tanggal 31 Juli 2017 di ruang Bali Desa Kertayasa Kecamatan Cijulang Kabupaten Pangandaran dengan mengambil tema Pemberdayaan Masyarakat Pantai Melalui Pengemasan Produk Destinasi Wisata dalam Perspektif Komunikasi Visual di Desa Kertayasa Kecamatan Cijulang Kabupaten Pangandaran. Adapun narasumbernya adalah Syauqi Luqman, S.Sos, M.M yang menyampaikan tentang pentingnya masyarakat berdaya ekonomi melalui berbagai kegiatan yang mengandung unsur potensi lokal. Sedangkan narasumber kedua, yaitu Dr. Yanti Setianti, M.Si menyampaikan tentang kekuatan kearifan lokal yang bisa menumbuhkan kekreatifitasan seseorang atau lembaga dalam meningkatkan aspek perekonomian di suatu daerah.

Pemberdayaan masyarakat melalui pelatihan komunikasi visual dengan memanfaatkan new media dan potensi lokal sebagai salah satu kearifan lokal di maksudkan untuk memanfaatkan modal sosial yang ada di masyarakat Desa Kertayasa. Modal sosial merupakan hal yang sangat penting dalam program pemberdayaan masyarakat. Cohen \& Prusak (Iriana Bakti, 2016) menuliskan konsep awal modal sosial ditulis oleh Hanifan di tahun 1916, saat dia membicarakan tentang pusat komunitas yang terkait dengan sekolah di wilayah pedesaan. Hanifan menggunakan istilah modal sosial untuk membicarakan faktor substansi dalam kehidupan masyarakat yang antara lain berupa niat baik (good will, rasa simpati, perasaan persahabatan, dan hubungan sosial yang membentuk sebuah unit sosial.

Kegiatan PKM ini diikuti oleh para peserta yang terdiri dari komunitas penggerak wisata, kader PKK, serta unsur pemuda, perangkat desa dan tokok masyarakat. Dalam kesempatan ini, mereka menyampaikan bahwa memang benar di desa Kertayasa memiliki sekian banyak potensi lokal yang bisa dimanfaatkan oleh warga masyarakatnya, namun sampai saat ini belum optimal. 


\section{Potensi Wisata Alam Cukangtaneuh}

Beberapa objek wisata yang terdapat di Kabupaten Pangandaran dan masih dapat dikembangkan adalah : Pantai Pangandaran, Taman Wisata Alam (cagar alam pananjung), Pantai batu hiu, pantai Batu Karas, pantai madasari, pantai karapyak, dan wisata sungai yaitu cukang taneuh (green canyon), citumang, dan santirah. Di sekitar destinasi wisata tersebut tersedia fasilitas hotel dengan kelas yang bervariasi dan cukup lengkap, selain hotel terdapat pula restoran, dan tempat hiburan lainnya. Sehingga pengunjung tidak perlu bingung untuk mencari tempat istirahat, dan menikmati destinasi wisata yang berbeda, yang paling terkenal saat ini adalah olahraga rekreasi yang terdapat disejumlah titik di Pangandaran yang dulunya hanya dikenal karena pantai nya saja.

Cukangtaneuh atau lebih dikenal dengan nama green canyon merupakan destinasi wisata berbasiskan potensi alam yang ada di Desa Kertayasa. Pada saat ini pengelolaannya dilakukan oleh desa bekerjasama dengan tokoh pemuda. Promosi dilakukan melalui website dan sosialiasi oleh dinas pariwisata Pangandaran.

Kemajuan Pangandaran sedikit demi sedikit telah ada perkembangan, seperti hotel yang tadinya sedikit sekarang telah banyak. Akses menuju Pangandaran memang masih kurang bagus, tapi hal tersebut harus dibicarakan dengan orang yang berkompeten, salah satunya bapak Jokowi. Anakanak dan masyarakat bisa menilai mengenai transportasi kurang baik, jembatan saja belum bisa diselesaikan karena di lelang dan belum ada yang mau menerima. Jembatan Putrapinggan bukan tanggung jawab Bupati, tetapi investor yang masuk, Bupati hanya sebagai pemilik daerah saja. Jika menunggu subsidi dari Provinsi memerlukan proses dan waktu. Tidak begitu saja Provinsi mengucurkan dana ke daerah Pangandaran, hal tersebut berdasarkan aturan. Sebetulnya jika Bupati kritis, jangka pendeknya transportasi dipenuhi terlebih dahulu, dan selanjutnya perkantoran dipenuhi. Seharusnya dalam hal penataan itu berada diakhir, karena segala sesuatu tergantung pada materi. Perbaikan mengenai Pangandaran adalah masyarakat yang kompak dan jujur. Segala permasalahan pemerintah tidak boleh diatur oleh premanisasi, di Pangandaran masih banyak premanisasi dan perlu diperbaik. Pengelolaan didalam seharusnya ada ketegasan, kejujuran dan keadilan, tidak hanya sekedar visi misi saja yang bagus di awal tapi nyatanya tidak sesuai.

Meskipun begitu masih banyak wisatawan yang datang ke Pangandaran dan berpendapat bahwa Pangandaran berkembang dengan cukup signifikan, tak hanya wisatawan domestic tetapi juga wisatawan asing. Mayoritas wisatawan asing datang ke Pangandaran pada bulan Juni dan Agustus, hal ini dikarenakan di negara subtropis mulai memasuki musim gugur, dimana pada saat itu hawa dingin mulai terasa, dengan berlibur ke daerah pantai wisatawn asing dapat merasakan sinar matahari.

Volume 2, Number 1, Mei 2018|33

Pemberdayaan Masyarakat Pantai melalui Pelatihan Pengemasan Produk Destinasi Wisata dalam Perspektif Komunikasi Visual di Desa Kertayasa Kecamatan Cijulang Kabupaten Pangandaran Yanti Setianti, Hanny Hafiar, Priyo Subekti 
Waktu datang pun menentukan tujuan, wisatawan asing yang datang ke Pangandaran sebagian memiliki tujuan untuk tour, dan biasanya melakukan snorklling serta berselancar. Banyak daerah wisata yang biasa dikunjungi oleh wisatawan asing di Pangandaran yaitu daerah Citumang, Karangtaulan, Cigugur, Masawah, Bojong Salawe, Green Canyon, Karang Nini, dan lain-lain.

Selain itu untuk menunjang perbaikan pariwisata di Pangandaran yang berbasis riset dan sesuai dengan target, penulis telah melakukan wawancara baik secara formal maupun informal kepada wisatawan, Kompepar, masyarakat asli Pangandaran, dan pelaku wisata yang ada di Pangandaran sebagai perbandingan sehingga nantinya dapat dihasilkan langkah yang sesuai dengan apa yang dibutuhkan semua kalangan dan meminimalisir kemungkinan adanya pro-kontra di masyarakat. Baik itu dari segi penataan atau kebijakan mendatang ynag akan dikeluarkan oleh Pemerintah Kabupaten Pangandaran, promosi yang tepat untuk membuat Pangandaran lebih dikenal, muapun hal lain untuk perkembangan Pangandaran yang tidak hanya berdarsarkan perkiraan saja.

Dari hasil wawancara yang telah dilakukan, penulis juga dapat mengetahui apa saja potensi pariwisata yang ada di Pangandaran, bagaimana cara pengembangan objek wisata yang sesuai dengan keinginan wisatawan serta mengetahui apa saja permasalahan pariwisata di Pangandaran baik yang internal maupun eksternal, serta pro dan kontra dari kebijakan Pemerintah Kabupaten Pangandaran.

Salah satu faktor yang paling penting adalah pendapat wisatawan mengenai Pangandaran, baik dari kesan, kenyamanan, keamanan, maupun destinasi wisata baru yang dibuka, setelah melakukan beberapa wawancara penulis dapat melihat Pangandaran dari sudut pandang lain yang bisa dijadikan sebagai referensi bagi masyarakat Pangandaran untuk semakin meningkatkan kualitas pariwisatanya.

Hal yang tak kalah mengejutkan adalah suara dari pedagang sekaligus warga asli Pangandaran yang memberikan pendapat mengenai kebijakan yang di lakukan Pemerintah, yang membuat penulis dapat membuka pandangan lebih luas dan berpikir terbuka mengenai permasalahan yang ada di Pangandaran khususnya mengenai pariwisata. Hal senada juga diungkapkan oleh pelaku wisata lain yang menyuarakan pendapatnya mengenai kebijakan lain, termasuk kompepar yang menginginkan agar Pemerintah khususnya Dinas untuk lebih meningkatkan kualitas promosi yang dilakukannya .

Bidang budaya mencangkup seni dan situs. Dalam seni disini maksudnya untuk melatih anakanak menari atau hal lainnya yang menjurus ke arah budaya. Sedangkan untuk situs, dinas pariwisata akan mendata beberapa situs yang ada di pangandaran dari mulai situs supranatural sampai yang natural. Sehingga Pangandaran tidak hanya dikenal kerana pantai dan sunset-nya saja. Dengan

Volume 2, Number 1, Mei 2018| 34

Pemberdayaan Masyarakat Pantai melalui Pelatihan Pengemasan Produk Destinasi Wisata dalam Perspektif Komunikasi Visual di Desa Kertayasa Kecamatan Cijulang Kabupaten Pangandaran 
mengembangkan potensi budaya yang ada di Pangandaran diharapkan dapat menjadi salah satu daya jual baru yang semakin menarik banyak pengunjung ke Pangandaran. Budaya yang saat ini mulai berkembang yaitu seni tari Ronggeng gunung, ini terlihat dari makin banyaknya sanggar tari di Pangandaran dengan peminat yang cukup banyak, tentunya ini menjadi suatu perkembangan yang baik untuk menunjukan kebudayaan yang ada di Pangandaran. Ronggeng gunung biasanya ditampilkan dihari besar, festival-fastival, dan penyambutan tamu-tamu penting yang ada di Pangandaran. Yang paling baru adalah saat penyambutan Menpora dan Kemenristek Diktipada tanggal 13 Maret 2017 untuk penandatanganan MoU PSDKU Unpad Pangandaran dan IPB Cirebon.

Begitu banyak potensi yang ada di Pangandaran khususnya Desa Kertayasa, melalui pelatihan komunikasi visual maka dapat dimunculkan beberapa inovasi dalam pengembangan potensi alam dan budayanya yakni:

1) Pemanfaatan media sosial dan media internet untuk promosi destinasi wisata Cukangtaneuh dan potensi wisata budaya seni badud.

2) Pengelolaan Media sosial dan internet saat ini sudah dilakukan oleh Kompepar dan Pemerintah Kabupaten Pangandaran, hanya pengemasan desain pesannnya harus dibenahi agar mampu menarik wisatawan dan secara komunikasi visual 'menjual”'

3) Pelatihan sumber daya manusia di Desa Kertayasa agar mampu mengelola media sosial dan internet. Karena promosi menggunakan media sosial dan internet tidak membutuhkan biaya yang besar dan jangkauannya melewati ruang dan waktu dalam artian dapat menjangkau khalayak dengan cepat dan luas.

\section{Simpulan}

Sebagai kesimpulan dari kegiatan Pengabdian Kepada Masyarakat ini yaitu dengan adanya pemberdayaan masyarakat pantai melalui pengemasan produk destinasi wisata dalam perspektif komunikasi visual di Desa Kertayasa Kecamatan Cijulang Kabupaten Pangandaran dapat membantu mengatasi keterbatasan peserta dalam hal mampu membuat desain website destinasi wisata yang menarik dan mampu membuat desain pengemasan produk yang lebih menarik dan menjual.

Kegiatan pelatihan ini sebagai sebuah upaya bimbingan teknis, khususnya dalam meningkatkan dan mengembangkan potensi masyarakat terutama dalam hal promosi dan pemasaran

Volume 2, Number 1, Mei 2018| 35

Pemberdayaan Masyarakat Pantai melalui Pelatihan Pengemasan Produk Destinasi Wisata dalam Perspektif Komunikasi Visual di Desa Kertayasa Kecamatan Cijulang Kabupaten Pangandaran Yanti Setianti, Hanny Hafiar, Priyo Subekti 
Adapun saran yang dapat disampaikan melalui laporan kegiatan Pengabdian Kepada Masyarakat ini yaitu:

1. Kegiatan semacam ini perlu terus difasilitasi sebagai sebuah kegiatan pengabdian pada masyarakat karena memiliki tujuan dan manfaat yang jelas.

2. Bagi peserta yang telah mendapatkan pelatihan diharapkan mampu mendalami apa yang telah disampaikan.

3. Peserta pelatihan dapat mulai mencoba menganalisis pemberitaan di media massa dan membuat release.

\section{Daftar Referensi}

Dwiyanto. Reformasi Tata Pemerintahan dan Otonomi Daerah. Yogyakarta: PSKK UGM. 2002.

Iriana Bakti, P. S. . Identifikasi Potensi Modal Sosial Dalam Perancangan Model CSR Di Kabupaten Bandung Barat. Membangun Etika Komunikasi Politik dalam Ruang Media Massa (hal. 129-137). Tuban: FISIP Universitas PGRI Ronggolawe . 2016.

Prijono, \& Pranarka. Pemberdayaan: Konsep, Kebijakan dan Implementasi. Jakarta: Center for Strategic and International Studies. 1996.

Sumodiningrat, G. Pemberdayaan Masyarakat dan Jaring Pengaman Sosial. Jakarta: Gramedia.1999

Sutoro, E. Pemberdayaan Masyarakat Desa, Samarinda: Diklat Pemberdayaan Masyarakat Badan Diklat Provinsi Kaltim. 2002.

Vidhandika. Pemberdayaan (Empowerment). Jakarta: CSIS.2006. 